\title{
Prevalence of Helicobacter pylori vacA, cagA, iceA and oipA genotypes in Tunisian patients
}

\author{
Khansa Ben Mansour ${ }^{1 *}$, Chédlia Fendri ${ }^{1}$, Meriem Zribi ${ }^{1}$, Afef Masmoudi ${ }^{1}$, Mounir Labbene $^{2}$, Azza Fillali ${ }^{3}$, \\ Nabil Ben Mami ${ }^{4}$, Taoufik Najjar ${ }^{5}$, Ahmed Meherzi ${ }^{6}$, Tahar Sfar ${ }^{7}$, Christophe Burucoa ${ }^{8}$
}

\begin{abstract}
Background: Distinct virulence factors of H. pylori have been described: the vaculating cytotoxin (vacA), the cytotoxin associated gene (cagA), the induced by contact with epithelium factor Antigen (iceA gene) and the outer membrane protein oipA. In Tunisia, there are no data regarding the pattern of H. pylori genotypes; therefore, this prospective and multicentre study was the first to be done in Tunisia and aimed to investigate the prevalence of the vacA, cagA, iceA and oipA genotypes of $\mathrm{H}$. pylori isolates from Tunisian patients with peptic ulceration, gastric cancer, MALT lymphoma and gastritis.

Methods: H. pylori was cultured from endoscopic biopsies obtained from 281 Tunisian patients. The vacA alleles, cagA, iceA and oipA genotypes were determined by PCR.

Results: The vacA s1m1, s1m2 and s $2 \mathrm{~m} 2$ were respectively found in $10.7 \%, 12.5 \%$ and $45.6 \%$ of strains. The $s 2 \mathrm{~m} 1$ genotype was not detected in our study. The cagA was found in $61.6 \%$ of isolates. The iceA1 and the iceA2 genotypes were respectively isolated in $60.2 \%$ and in $16 \%$ of strains. The oipA genotype was detected in $90.8 \%$ of strains. Considering the vacA and iceA genotypes, the presence of multiple $H$. pylori strains in a single biopsy specimen was found respectively in $31.4 \%$ and $23.8 \%$. The comparison between strains isolated from antrum and fundus showed that Tunisian patients were infected with two or more strains of different cagA, vacA, iceA and oipA genotypes and the discordance was respectively in $9.6 \%, 4.6 \%, 8.9 \%$ and $8.5 \%$ of strains.

Conclusion: Our results showed that in 46\% (131 strains among 281), the $H$. pylori strains were highly virulent in relation of the three or four virulent factors they could carry. These finding were described before in the literature. Tunisian patients were colonized by one or multiple strains of $\mathrm{H}$. pylori in the same time in relation of presence of vacA $\mathrm{m} 1 / \mathrm{m} 2$ and iceA1/iceA2 in the same biopsy. The discordance between strains isolated from antrum and fundus was high, and it is in favour of multicolonization.
\end{abstract}

\section{Background}

Helicobacter pylori (H. pylori) is one of the most common bacterial pathogens of humans and has a worldwide distribution. Infection by $H$. pylori is associated with the development of chronic gastritis, gastric or duodenal ulcer, gastric cancer and MALT-lymphoma [1]. Different virulence genes have been described in $H$. pylori infection such as cagA, vacA, ice $A$ and oip $A$ genes. The cytotoxin-associated gene $(\operatorname{cag} A)$ is frequently associated with cytotoxin production and the induction of interleukin 8 (IL8) by gastric epithelial cells [2]. Several studies have suggested that cagA is a useful

\footnotetext{
* Correspondence: bmkhansa@gmail.com

'Microbiology laboratory/UR04SP08 Rabta University Hospital, Tunis, Tunisia
}

marker for the most virulent strains that are associated with peptic ulcer, atrophic gastritis and adenocarcinoma [3-5]. The cag pathogenicity island (PaI) encodes a type IV secretory system and delivers CagA into the host cytosol where becomes phosphorylated on tyrosine residue. Phosphorylated CagA interacts with the phosphatase SHP-2 causing dephosphorylation of cortactin and cytoskeletal rearrangements forming the "hummingbird" phenotype [6]. The vacuolating cytotoxin gene (vacA) is an important virulence factor encoding the vacuolating toxin and it is present in all strains $[7,8]$. There is a considerable variation in vacuolating activities among strains [9-11] due to the sequence heterogeneity at the middle $(\mathrm{m})$ and the signal $(\mathrm{s})$ regions within the $v a c A$ gene. The middle region has $\mathrm{m} 1$ and $\mathrm{m} 2$ allelic types 
and the signal region located at the 5 ' end of the gene has an s1 (s1a, s1b and s1c) or an s2 allele. Strains carrying the $\mathrm{s} 1 \mathrm{ml}$ mosaic combination of the gene vacA exhibit higher levels of cytotoxic activity than $\mathrm{s} 1 \mathrm{~m} 2$ strains, while $\mathrm{s} 2 \mathrm{~m} 2$ strains do not secrete the vacuolating cytotoxin [12]. Another virulence gene designated ice $A$ (for induced by contact with epithelium) has been recently described. The ice $A$ gene has two main allelic variants ice $A 1$ and ice $A 2$ [13] but the function of these variants is not yet clear [14-18]. iceA1 is upregulated upon contact of $H$. pylori with the gastric epithelium and has been regarded as a marker for peptic ulcer disease [19]. Recently, a novel putative virulence factor has been identified, the oipA (outer inflammatory protein) gene, which encodes one of the outer membrane proteins and is an inflammation-related gene located approximately $100 \mathrm{~kb}$ from the cag PAI on the $H$. pylori chromosome [20]. oipA induces IL-8 secretion by epithelial cells and active OipA protein production may be "on" or "off" depending on the number of CT dinucleotide repeats in the signal sequence of the oip $\mathrm{A}$ gene (HP0638) [21].

In Tunisia, there are no data regarding the pattern of $H$. pylori genotypes in patients; therefore, our prospective and multicentre study was the first to be done in Tunisia and to our knowledge the first one in North Africa. It aimed to investigate the prevalence of the vacA, cagA, ice $A$ and oipA genotypes of $H$. pylori isolates from Tunisian patients.

\section{Materials and methods Materials}

Biopsy samples were obtained over a 2 years-period (March 2005 to August 2007) from patients referred for endoscopy at 6 centers of gastroenterology in Tunisia. 281 patients, who had $H$. pylori positive cultures, were enrolled in this study. The mean age of the patients was 39.9 (range, 2 to 88 ) and 54.4\% were women. Regarding macroscopic aspect of the mucosa and histological routine results, patients were distributed into gastritis in 195 cases (69.3\%), peptic ulceration in 78 cases $(27.7 \%)$ (duodenal ulcer in 67 cases, gastric ulcer in 11 cases), MALT lymphoma of the stomach in one case $(0.3 \%)$ and gastric cancer in 7 cases $(2.5 \%)$. One endoscopic biopsy specimen taken from the antrum and one taken from the fundus were immediately frozen and kept separately at $-80^{\circ} \mathrm{C}$. In addition, one biopsy specimen from the antrum and one from the fundus were used for the culture. In our study, we also obtained colonies isolated separately from two biopsy sites (antrum and fundus) to determine if one patient can be colonized with one or more strains of $H$. pylori. All subjects were answering to questionnaire related to age, sex, gastric or duodenal peptic ulcer diseases upon endoscopy.

\section{Culturing of H. pylori and DNA extraction}

The biopsy specimens were cut into small pieces, homogenized in a Petri dish with a sterile scalpel and were smeared on the surface of Columbia agar plates containing 10\% horse blood and Skirrow (Oxoid, England) supplement. Incubation was performed in microaerophilic conditions at $37^{\circ} \mathrm{C}$ for a maximum of 6 days. The $H$. pylori colonies were smooth, translucent and small ( $2 \mathrm{~mm}$ of diameter). In our study, the antral and fundic biopsy specimens were studied separately. Colonies that exhibited the described characteristic morphologies were identified as $H$. pylori if they were Gram negative and shaped bacilli, and urease, catalase and oxidase positive. From the primary growth, seven or eight colonies were pooled together, and genomic DNA was extracted with the QIAamp DNA mini kit (Qiagen, Germany) according to the manufacturer's instructions. The isolated DNA was eluted in $200 \mu \mathrm{l}$ of $1 \times$ TE buffer $(10 \mathrm{mM}$ Tris- $\mathrm{HCl}, 1 \mathrm{mM}$ EDTA $[\mathrm{pH} 8.0])$ and stored at $-20^{\circ} \mathrm{C}$ until use.

\section{H. pylori genotyping}

After DNA extraction, polymerase chain reactions (PCR) were performed in a volume of $50 \mu \mathrm{l}$ containing $1 \mu \mathrm{M}$ of each primers, $1 \mu \mathrm{L}$ of genomic DNA (approximately $200 \mathrm{ng}$ ), $1 \mathrm{mM}$ of dNTPs mix (invitrogen), $2 \mathrm{mM}$ of $\mathrm{MgCl}_{2}$, and $0.05 \mathrm{U} / \mu \mathrm{L}$ Taq DNA polymerase (invitrogen). PCR amplifications were performed in an automated thermal cycler (Biometra Co., Germany). Table 1 summarized the primer sequences and the expected size of PCR products. The following cycle conditions were used: for vacA: 35 cycles of $1 \mathrm{~min}$ at $94^{\circ} \mathrm{C}, 1 \mathrm{~min}$ at $53^{\circ} \mathrm{C}$, and $1 \mathrm{~min}$ at $72^{\circ} \mathrm{C}$; for $\operatorname{cag} A$ : $1 \mathrm{~min}$ at $94^{\circ} \mathrm{C}, 1 \mathrm{~min}$ at $56^{\circ} \mathrm{C}$, and $1 \mathrm{~min}$ at $72^{\circ} \mathrm{C}$; for ice $A$ : $1 \mathrm{~min}$ at $94^{\circ} \mathrm{C}$, $1 \mathrm{~min}$ at $56^{\circ} \mathrm{C}$, and $1 \mathrm{~min}$ at $72^{\circ} \mathrm{C}$, and for oipA: $1 \mathrm{~min}$ at $94^{\circ} \mathrm{C}, 1 \mathrm{~min}$ at $56^{\circ} \mathrm{C}$ and $1 \mathrm{~min}$ at $72^{\circ} \mathrm{C}$. All runs included one negative DNA control consisting of PCRgrade water and two or more positive controls (26695, J99, SS1, Tx30, 88-23 and 84-183). The amplified PCR products were resolved in $1.5 \%$ agarose gels stained with ethidium bromide and visualized under a short wave length ultraviolet light source.

\section{Statistical analysis}

Data were analyzed using $X^{2}$ test. A $p$ value of $<0.05$ was considered to be statistically significant.

\section{Results}

\section{cagA genotyping}

The 349-bp PCR product indicating the presence of the cagA gene was obtained with 173 isolates (61.6\%) and $108(38.4 \%)$ were negative. We showed cagA genotype discordance between antrum and fundus in 27 isolates (9.6\%) (Table 2). 
Table 1 PCR primers for amplification of $\operatorname{cag} A$, vacA, ice $A$ and oipA sequences

\begin{tabular}{|c|c|c|c|c|}
\hline Region & Primer & Primer sequence $\left(5^{\prime}-3^{\prime}\right)$ & Size of PCR product (bp) & References \\
\hline \multirow[t]{2}{*}{$\operatorname{cag} A$} & F1 & GATAACAGCCAAGCTITTGAGG & 349 & [36] \\
\hline & B1 & CTGCAAAAGATTGTTTGGCAGA & & \\
\hline \multicolumn{5}{|l|}{$\operatorname{vac} A$} \\
\hline \multirow[t]{2}{*}{$\mathrm{m} 1$} & VA3-F & GGTCAAAATGCGGTCATGG & 290 & \\
\hline & VA3-R & CCATTGGTACCTGTAGAAAC & & \\
\hline \multirow[t]{2}{*}{$\mathrm{m} 2$} & VA4-F & GGAGCCCCAGGAAACATTG & 352 & \\
\hline & VA4-R & CATAACTAGCGCCTTGCAC & & \\
\hline \multirow[t]{2}{*}{$\mathrm{s} 1 / \mathrm{s} 2$} & VA1-F & ATGGAAATACAACAAACACAC & $259 / 286$ & [12] \\
\hline & VA1-R & CTGCTTGAATGCGCCAAAC & & \\
\hline \multirow[t]{2}{*}{$s 1 b$} & SS3-R & AGCGCCATACCGCAAGAG & 187 & \\
\hline & VA1-R & CTGCTTGAATGCGCCAAAC & & \\
\hline \multirow[t]{2}{*}{ sla } & SS1-R & GTCAGCATCACACCGCAAC & 190 & \\
\hline & VA1-R & CTGCTTGAATGCGCCAAAC & & \\
\hline \multirow[t]{2}{*}{ s2 } & $S S 2-R$ & GCTAACACGCCAAATGATGC & 199 & \\
\hline & VA1-R & CTGCTTGAATGCGCCAAAC & & \\
\hline \multirow[t]{2}{*}{ iceA1 } & iceA1-F & GTGTTITTAACCAAAGTATC & 247 & {$[37]$} \\
\hline & iceA1-R & CTATAGCCASTYTCTITGCA & & \\
\hline \multirow[t]{2}{*}{ iceA2 } & iceA2-F & GTTGGGTATATCACAATTTAT & 229/334 & {$[37]$} \\
\hline & iceA2-R & TTRCCCTATTTTCTAGTAGGT & & \\
\hline \multirow[t]{2}{*}{ oipA } & HPO638F & GTITTTGATGCATGGGATTT & 401 & [38] \\
\hline & HPO638R & GTGCATCTCTTATGGCTIT & & \\
\hline
\end{tabular}

Table 2 Prevalence of $\boldsymbol{H}$. pylori genotypes detected in strains

\begin{tabular}{lc}
\hline Genotype & Prevalence \\
\hline cagA & \\
cagA + & $173(61.6 \%)$ \\
cagA - & $108(38.4 \%)$ \\
$\mathrm{d}(\mathrm{A} / \mathrm{F})^{*}$ & $27(9.6 \%)$ \\
vacA & \\
$\mathrm{m} 1 \mathrm{~s} 1 \mathrm{a}$ & $5(1.8 \%)$ \\
$\mathrm{m} 1 \mathrm{~s} 1 \mathrm{~b}$ & $25(8.9 \%)$ \\
$\mathrm{m} 2 \mathrm{~s} 1 \mathrm{a}$ & $10(3.5 \%)$ \\
$\mathrm{m} 2 \mathrm{~s} 1 \mathrm{~b}$ & $25(8.9 \%)$ \\
$\mathrm{m} 2 \mathrm{~s} 2$ & $128(45.6 \%)$ \\
$\mathrm{m} 1 \mathrm{~m} 2$ & $88(31.4 \%)$ \\
$\mathrm{m} 1 \mathrm{~s} 2$ & $0(0 \%)$ \\
$\mathrm{d}(\mathrm{A} / \mathrm{F})^{*}$ & $13(4.6 \%)$ \\
iceA & \\
iceA1 & $169(60.2 \%)$ \\
iceA2 & $45(16 \%)$ \\
iceA1/iceA2 & $67(23.8 \%)$ \\
$\mathrm{d}(\mathrm{A} / \mathrm{F})^{*}$ & $25(8.9 \%)$ \\
oipA & \\
oipA + & $255(90.8 \%)$ \\
oipA - & $26(9.2 \%)$ \\
$\mathrm{d}(\mathrm{A} / \mathrm{F})^{*}$ & $24(8.5 \%)$ \\
\hline if & \\
\hline
\end{tabular}

$d(A / F)^{*}$ : discordance between strains isolated from the antrum and the fundus in the same patient

\section{vacA genotyping}

The vacA s- and $\mathrm{m}$ - region genotype were determined in all strains studied. In the m-region, 88 strains contained both $\mathrm{m} 1$ and $\mathrm{m} 2$ alleles. In the strains containing one single $v a c A \mathrm{~m}$ allele, the $\mathrm{m} 1$ allele was found in 30 isolates (10.7\%) and $\mathrm{m} 2$ in 163 one (58\%).

For the s-region, in strains where a single vacA s allele was found, the majority $128(45.6 \%)$ contained the s2 allele. In 65 isolates contained s1 allele (23.2\%), 50 (77\%) were subtype s1b while only 15 (23\%) were subtype s1a.

Considering strains with only one single vacA genotype, and taking vacA s- and m-region together, three genotypes were found: $\mathrm{s} 1 / \mathrm{m} 1$ (10.7\%), s1/m2 (12.5\%) and $\mathrm{s} 2 \mathrm{~m} 2(45.6 \%)$. The $\mathrm{s} 2 \mathrm{~m} 1$ genotype was not found in our study.

The discordance between strains taken from antrum and those from fundus was found in 13 cases $(4.6 \%)$ (Table 2).

\section{iceA genotyping}

Overall, ice $A 1$ was detected in 169 strains (60.2\%) of all 281 isolates and ice $A 2$ was found in 45 strains (16\%). In the present study, the ice $A 2$ amplification yielded both the $229 \mathrm{bp}$ and $334 \mathrm{bp}$ fragments (figure 1), this difference in the fragment size is due to the presence of a $105 \mathrm{bp}$ in - frame amplicon present in the $334 \mathrm{bp}$ fragment that 


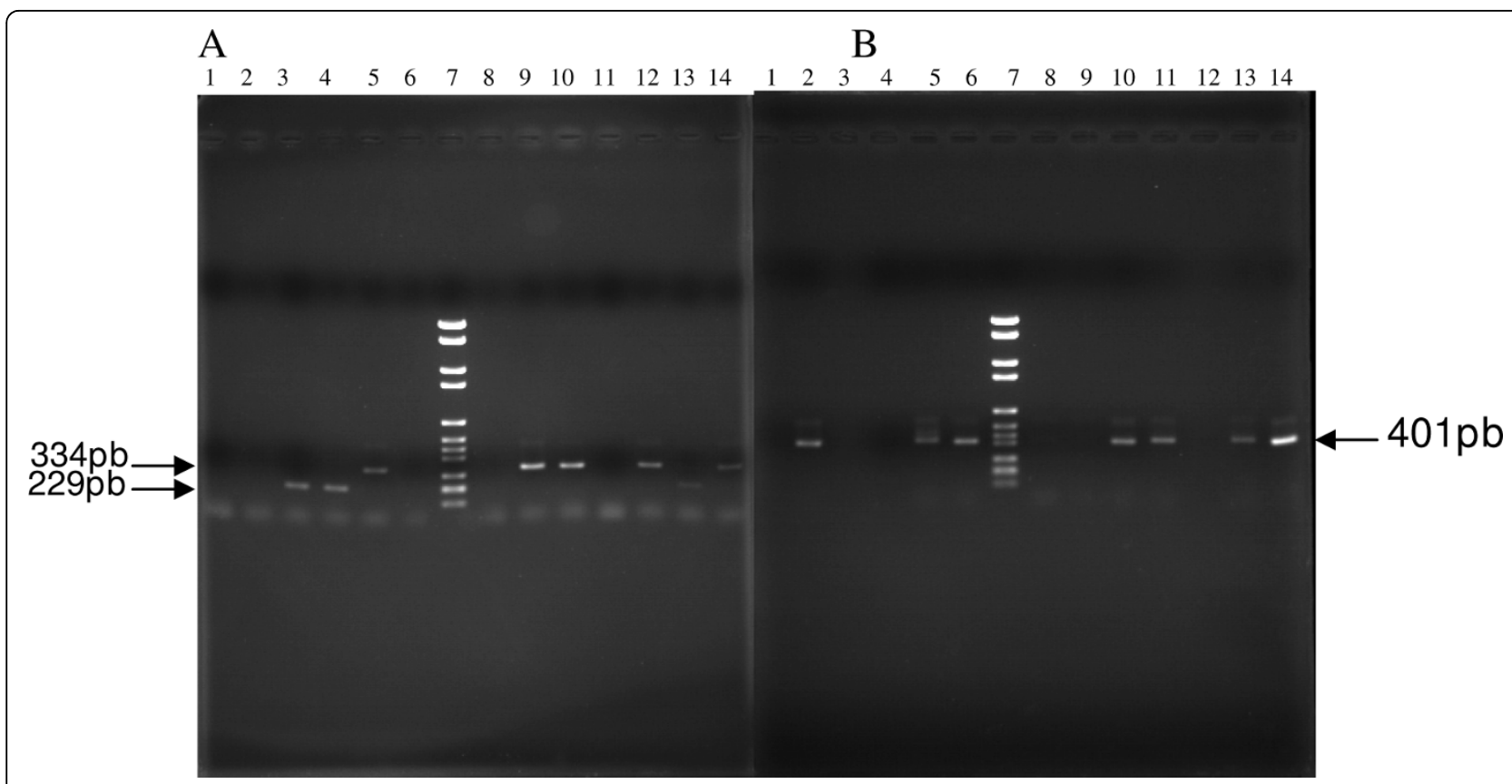

Figure 1 Genotyping of iceA2 and oipA genes by PCR. A: example of iceA2 genotyping. Lane 1, negative control without DNA, Lanes 2, 6, 8 and11, iceA2 negative H. pylori strain, Lanes 3, 4 and 13, iceA2 positive $H$. pylori strain (229-bp), Lanes, 5, 9, 10, 12 and 14, iceA2 positive strain (334-bp), Lane 7,100-bp DNA marker. B: example of oipA genotyping. Lane 1, negative control without DNA, Lanes 2, 5, 6, 10, 11, 13 and 14, oipA positive strains, Lane 7, 100-bp DNA marker, Lanes 3, 4, 8, 9 and 12, oipA negative strains.

is absent in the $229 \mathrm{bp}$ fragment [22]. Sixty-seven strains (23.8\%) were positive for both $i c e A 1$ and $i c e A 2$, and discordance between isolates from antrum and fundus was seen in 25 strains $(8.9 \%)$ (Table 2).

\section{oipA genotyping}

The oipA genotype was detected in 255 (90.8\%) from 281 strains, and only 26 strains $(9.2 \%)$ were oipA negative. The discordance between strains obtained from antrum and fundus was determined in 24 strains $(8.5 \%)$ (Table 2). The 401-bp PCR product indicating the presence of the oipA gene was shown in figure 1 .

\section{Combined cagA, vacA, iceA and oipA genotypes}

Based on analysis of the cagA gene (positive and negative), the $v a c A$ s-region (s1 and s2), the iceA allelic type (iceA1 and iceA2) and the oipA gene (positive and negative), ten different genotypic combinations were recognized (Table 3). The prevalence of each of these genotypes among the 131 strains with a single combined genotype was shown in table 3 . The most prevalent genotypes were $\mathrm{s} 2 /$ cagA+/iceA1/oipA+ (27.5\%), s2/cagA-/ iceA1/oipA + (23.6\%), s2/cagA+/iceA2/oipA+ (11.4\%) and $\mathrm{s} 1 /$ cagA+/iceA1/oipA+ (9.9\%). Among the strains isolated from 24 ulcer patients (gastric and duodenal ulcer) with a single genotype, 8 strains (33.3\%) contained the vacA $\mathrm{s} 1 /$ cag $A+$ /ice $A 1$ genotype while only one $(4.1 \%)$ contained $v a c A$ s1/cagA-/iceA2. If we consider only vacA
Table 3 Combined vacA, cagA, iceA and oipA genotypes

\begin{tabular}{lcccc}
\hline Combination & DU* & GU* & $\mathbf{G}^{*}$ & Total \\
\hline s1/cagA+/iceA1/oipA+ & $4(20 \%)$ & $4(100 \%)$ & $7(6.5 \%)$ & $13(9.9 \%)$ \\
s1/cagA+/iceA2/oipA+ & $4(20 \%)$ & $0(0 \%)$ & $4(3.7 \%)$ & $8(6.1 \%)$ \\
s1/cagA-/iceA1/oipA+ & $8(40 \%)$ & $0(0 \%)$ & $3(2.8 \%)$ & $11(8.4 \%)$ \\
s1/cagA-/iceA2/oipA+ & $1(5 \%)$ & $0(0 \%)$ & $4(3.7 \%)$ & $5(3.8 \%)$ \\
s1/cagA+/iceA1/oipA- & $2(10 \%)$ & $0(0 \%)$ & $1(0.9 \%)$ & $3(2.3 \%)$ \\
s2/cagA+/iceA1/oipA+ & $1(5 \%)$ & $0(0 \%)$ & $35(32.7 \%)$ & $36(27.5 \%)$ \\
s2/cagA+/iceA2/oipA+ & $0(0 \%)$ & $0(0 \%)$ & $15(14 \%)$ & $15(11.4 \%)$ \\
s2/cagA-/iceA1/oipA+ & $0(0 \%)$ & $0(0 \%)$ & $31(29 \%)$ & $31(23.6 \%)$ \\
s2/cagA-/iceA2/oipA+ & $0(0 \%)$ & $0(0 \%)$ & $4(3.7 \%)$ & $4(3 \%)$ \\
s2/cagA-/iceA2/oipA- & $0(0 \%)$ & $0(0 \%)$ & $5(4.6 \%)$ & $5(3.8 \%)$ \\
\hline Total & 20 & 4 & 107 & 131 \\
\hline DU: duoder
\end{tabular}

DU*: duodenal ulcer; GU*: gastric ulcer; $\mathrm{G}^{*}$ : gastritis

and cagA genotypes, 14 strains (58.3\%) isolated from 24 ulcer patients had genotype vacA s1/cagA+, and none (0\%) had vacA s2/cagA-. If we consider only $v a c A$ and ice $A, 18$ strains (75\%) contained genotype vacA s1/iceA1, and none $(0 \%)$ had $v a c A$ s2/iceA2. When we take only $v a c A$ and oipA genotypes, 21 strains (87.5\%) had genotype vacA s1/oipA+ and none (0\%) had vacA s2/oipA-. Comparing with strains isolated from patients having gastritis, we found that the prevalence of genotypes $v a c A$ $\mathrm{s} 1 /$ cagA+, vacA s1/iceA1 and vacA s1/oipA+ was $11.2 \%$, $10.3 \%$, and $16.8 \%$, respectively. The genotype vacA s1/ cagA+/iceA1/oipA + was found in 13 (9.9\%) of 131 
isolates, and 8 (61.5\%) of these are associated with a clinical diagnosis of peptic ulcer disease, whereas genotypes harbouring the s2 allele of $v a c A$ gene were predominant in the strains isolated from patients with gastritis.

In our study, first, we have studied the relationship between virulence genes (vacA, cagA, ice $A, \operatorname{oip} A)$ and the different gastroduodenal diseases, between the two groups (patients with peptic ulceration/patients with gastritis). When considering the vacA and oipA genes, the difference was statistically significant between the two groups ( $\mathrm{p}<0.001$ ), but, when considering the cagA and ice $A$ genes, this relation is not statistically significant $(\mathrm{p}>0.05)$ (Tables 4$)$. Second, we were interesting in studying the relationship between: a/the age of patients and virulence factors (Table 5 ) and b/the sex and virulence factors (Table 6). Our study showed that, among age, the difference was statistically significant between adults and children with the cagA and ice $A$ genes $(\mathrm{p}<0.05)$, but not significant when considering the vacA and oipA genes. When about sex, we have demonstrated that the difference between men and women was statistically significant among vacA, oip $A$ and ice $A$ genes $(\mathrm{p}<0.05)$, which was not statistically significant with the $\operatorname{cag} A$ gene.

Table 4 cagA, vacA, iceA and oipA status of $H$. pylori strains with different gastric diseases: a comparison between patients with peptic ulceration, and with gastritis

\begin{tabular}{cccc}
\hline & PU* $^{*}$ & $\mathbf{G}^{*}$ & $\boldsymbol{p}$ \\
\hline cagAt & $53(67.9 \%)$ & $114(58.4 \%)$ & $>0.05$ \\
oipA+ & $63(80.7 \%)$ & $186(95.3 \%)$ & $<0.001$ \\
iceA1 & $51(65.3 \%)$ & $113(57.9 \%)$ & \\
iceA2 & $12(15.3 \%)$ & $33(16.9 \%)$ & $>0.05$ \\
iceA1/A2 & $15(19.2 \%)$ & $49(25.1 \%)$ & \\
m1s1 & $12(15.3 \%)$ & $18(9.2 \%)$ & \\
m2s1 & $17(21.8 \%)$ & $17(8.7 \%)$ & \\
m1m2 & $49(62.8 \%)$ & $32(16.4 \%)$ & $<0.001$ \\
m2s2 & $0(0 \%)$ & $128(65.6 \%)$ & \\
\hline PU* & & &
\end{tabular}

$\mathrm{PU}^{*}$ : peptic ulceration; $\mathrm{G}^{*}$ : gastritis

Table 5 Relation between the age of patients and virulence factors

\begin{tabular}{cccc}
\hline & Adults & Children & $\boldsymbol{p}$ \\
\hline cagA + & 155 & 18 & $<0.001$ \\
oipAt & 209 & 46 & $>0.05$ \\
iceA1 & 137 & 32 & \\
iceA2 & 43 & 2 & 0.05 \\
iceA1/iceA2 & 53 & 14 & \\
m1s1 & 26 & 4 & \\
m2s1 & 31 & 4 & $>0.05$ \\
m1m2 & 72 & 16 & \\
m2s2 & 104 & 24 & \\
\hline
\end{tabular}

Table 6 Relation between the sex of patients and virulence factors

\begin{tabular}{cccc}
\hline & Male & Female & $\boldsymbol{p}$ \\
\hline cagA + & 84 & 89 & $>0.05$ \\
oipA+ & 111 & 144 & $<0.05$ \\
iceA1 & 78 & 91 & \\
iceA2 & 17 & 28 & 0.05 \\
iceA1/iceA2 & 40 & 27 & \\
m1s1 & 19 & 11 & $<0.001$ \\
m2s1 & 19 & 16 & \\
m1/m2 & 49 & 39 & \\
m2s2 & 40 & 88 &
\end{tabular}

\section{Discussion}

The predominant genotype in strains that were positive for H. pylori by PCR was the oipA (90.8\%), followed by the cagA gene $(61.6 \%)$, and the ice $A 1$ gene $(60.2 \%)$, while the ice $A 2$ was amplified only in 45 strains (16\%). Our results were in agreement with other studies conducted in Europe, Central and South America, and East Asia where a higher prevalence (67\% or more) of the $\operatorname{cag} A$ genotype was reported [22]. In Turkey [23], Korea and Japan, the prevalence of the ice $A 1$ genotype in patient with duodenal ulcer were respectively $68.8 \%$, $69.8 \%$ and $62.5 \%$ which is similar to our study, whereas ice $A 2$ was prevalent in the USA and Columbia [24]. The already mentioned similitude can be defined by the epidemiological resemblance in these countries.

For the vacA genotype, and when considering a single combined genotype, our results showed that the vacA s2 allele was predominant (45.6\%) followed by the vacA s1 allele (23.2\%). A study in Kuwait reported that vacA s1 and s2 types were detected in approximately equal numbers in biopsies obtained from patients of Middle-Eastern origin, while North Africans were predominantly infected with the s2 type [25].

The prevalence of $c a g A+$ strains in Tunisian peptic ulcer and those with gastritis was similar to that shown in the study from South Africa [26].

In a previous report by van Doorn et al (19), an association was found between the iceA1 allele and peptic ulcer disease. Other studies from Asia were suggesting that $v a c A, \operatorname{cag} A$ and ice $A$ genotypes were not associated with peptic ulcer disease [27]. These findings may reflect important geographic differences between $H$. pylori strains and patients. As reported by van Doorn et al, $H$. pylori genotypes are not uniformly distributed over the world [22]. When considering the $v a c A$ and oipA genes, our results showed that there is a significant difference between the two studied groups ( $\mathrm{p}<0.001$ ), but, cagA and $i c e A$ genes were not associated with gastroduodenal diseases in our study ( $\mathrm{p}>0.05)$. The oipA (HpO638) outer membrane protein expression was linked to severe 
inflammation and the induction of IL-8 secretion. In one Turkish study, oipA (HpO638) gene was highly associated with peptic ulcer disease $(92.9 \%)$ than with gastritis (80.9\%) [28]. In other studies, no difference in prevalence of $\operatorname{cagA}$ genotypes was found between peptic ulcers and other gastroduodenal diseases [29]. Yamaoka et al [24] reported that there was no association between the $i c e A, v a c A$ or $\operatorname{cag} A$ status and clinical outcome in studied patients.

In our study, the oipA gene was found in $100 \%$ of gastric ulcer. Several studies failed to show a relationship between the gene status and clinical symptoms in several patient populations, this might be due to that patient selection is extremely important and the study group should be sufficiently large and diverse with respect to genotypes and clinical symptoms.

As for age, we have demonstrated that the difference between children and adults was statistically significant about the $\operatorname{cag} A$ and ice $A$ genes, but not with the vacA and oip $A$ genes. Regarding the distribution of gene virulent factors according to sex, no difference seen in term of $\operatorname{cag} A$ gene, but the difference was statistically significant among the $v a c A$, ice $A$ and oip $A$ genes. In other reported studies, there were no significant differences in frequencies of $H$. pylori virulence-associated genes, between children and adults, and the strains from men exhibited genotypes similar to those in women [30]. Laila FN et al [31] have concluded in their study that the presence of certain genotypes was not significantly associated with the age or gender of the patient.

The detection of multiple genotypes implies the presence of multiple strains in a clinical sample. Considering $v a c A$ and ice $A$ genes in our study, the presence of multiple $H$. pylori strains in a single biopsy specimen was found respectively in $31.4 \%$ and $23.8 \%$. Then, when comparing the genetic differences in isolates of $H$. pylori from the antrum and the fundus, we determined that patients were infected with two or more strains of different $\operatorname{cag} A$, $v a c A$, ice $A$ and oip $A$, and the percentage of discordance was respectively in $9.6 \%, 4.6 \%, 8.9 \%$ and $8.5 \%$. Consequently, if multiple genotypes are found, this is a strong indication for the presence of multiple strains. It may be speculated that more than one strain may be acquired in childhood, especially in countries with a very high prevalence of $H$. pylori, but, it is not known whether multiple strains colonize simultaneously (coinfection) or at different time points (superinfection), and several studies demonstrated that coinfection or superinfection are common [32,33]. The co-existence of more than one strain in the same individual may reflect the capacity of $H$. pylori to evolve genetic variations during the long-term colonization from childhood [34], and the dynamics of cocolonization by multiple strains has been studied in animal models [35]. Since the prevalence of multiple strains colonization is clinically important in our study, there is a clear need to be considered when planning therapeutic strategies to avoid the risk of the emergence of such strains.

The present study showed that patients with peptic ulcer disease and those with gastritis were almost infected similarly by multiple strains of $H$. pylori. This underlines that the positive associations between $H$. pylori genotypes and peptic ulcer disease do not imply that patients without ulcer disease cannot be infected with high-risk $H$. pylori genotypes.

The combination of the distinct $v a c A, \operatorname{cag} A$, ice $A$ and oip $A$ genotypes illustrated the mosaic composition of the $H$. pylori genome. Strains typed as vacA s2/cagA + /ice $A+/$ oip $A+$ were more prevalent than those typed as vacA $\mathrm{s} 1 / \operatorname{cag} A+/$ ice $A+/$ oip $A+$ and which are associated to severe pathologies.

In conclusion, we have examined the prevalence of $v a c A, \operatorname{cag} A$, ice $A$ and oipA genotypes of $H$. pylori strains clinically isolated in Tunisia. No significant correlation was found between the expression of cagA and ice $A$ genes and the two groups of studied patients, but the difference was statistically significant with the $v a c A$ and oip $A$ genes. As for age, the difference between children and adults was statistically significant with the $\operatorname{cag} A$ and $i c e A$ genes, but not with oip $A$ and $v a c A$ genes. Regarding the distribution of virulence genes to sex, the difference was statistically significant among oip $A$, ice $A$ and $v a c A$ genes, but not with $\operatorname{cag} A$ gene.

In Tunisia, it is so possible that the high prevalence of infection with virulent factors contributes to the characteristics of $H$. pylori infection, but not used to discern the risk of developing serious gastroduodenal diseases in the host. Our results showed that Tunisian patients were colonized by one or more strains of $H$. pylori in relation of presence of $v a c A \mathrm{~m} 1 / \mathrm{m} 2$ and ice $A 1 /$ ice $A 2$ in the same biopsy, than, the discordance between strains isolated from antrum and fundus was higher, and it is in favour of multicolonization.

\section{Author details}

'Microbiology laboratory/UR04SP08 Rabta University Hospital, Tunis, Tunisia. ${ }^{2}$ Gastroenterology unit, Menzel Bourguiba Hospital, Tunisia.

${ }^{3}$ Gastroenterology A unit, Rabta University Hospital, Tunis, Tunisia.

${ }^{4}$ Gastroenterology B unit, Rabta University Hospital, Tunis, Tunisia. ${ }^{5}$ Gastroenterology unit, Charles Nicolle University Hospital, Tunis, Tunisia. ${ }^{6}$ Pediatric Unit Mongi Slim University Hospital, La Marsa, Tunis, Tunisia. ${ }^{7}$ Pediatric Unit Tahar Sfar Hospital, Mahdia, Tunisia. ${ }^{8}$ Université de Poitiers, EA 3807, Poitiers 86021, France; Laboratoire de bactériologie, Poitiers 86021 , France.

\section{Authors' contributions}

BMK was responsible for the collection of biopsies, $H$. pylori conventional culture, had carried out the molecular genetic studies, performed the statistical analysis, drafted the manuscript and participated in the design of the study. ZM and MA were participated in the design of the study. FA, BMN, NT, MA and ST were helped to the constitution of H. pylori strains 
collection. FC had conceived of the study, participated in its design and coordination and helped to draft the manuscript. Finally, BC had helped to molecular genetic studies and to draft the manuscript.

All authors have read and approved the final manuscript.

\section{Competing interests}

The authors declare that they have no competing interests.

This prospective multicentre study was performed in Microbiology

laboratory-Rabta University Hospital, Tunis, Tunisia in research unit UR04SP08.

Received: 19 November 2009 Accepted: 19 March 2010

Published: 19 March 2010

\section{References}

1. Blaser MJ: Ecology of Helicobacter pylori in the human stomach. J Clin Invest 1997, 100:759-762.

2. Jenks PJ, Mégraud F, Labigne A: Clinical outcome after infection with Helicobacter pylori does not appear to be reliably predicted by the presence of any of the genes of the cag pathogenicity island. Gut 1998 43:752-758.

3. Figura N, Guglielmetti P, Rossolini A: Cytotoxin production by Campylobacter pylori strains isolated from patients with peptic ulcers and from patients with chronic gastritis only. J Clin Microbiol 1989, 27:225-226.

4. Crabtree JE, Figura N, Taylor JD: Expression of 120 kilodalton protein and cytotoxicity in Helicobacter pylori. J Clin Pathol 1992, 45:733-734.

5. Blaser MJ, Perez-Perez Gl, Cover TL: Infection with Helicobacter pylori strains possessing CagA is associated with an increased risk of developing adenocarcinoma of stomach. Cancer Res 1995, 55:2111-2115.

6. Segal ED, Falkow S, Tompkins LS: Helicobacter pylori attachment to gastric cells induces cytoskeletal rearrangements and tyrosine phosphorylation of host cell proteins. Proc Natl Acad Sci USA 1996, 93:1259-1264.

7. Atherton JC: The clinical relevance of strain types of Helicobacter pylori. Gut 1997, 40:701-704

8. Cover TL: The vacuolating cytotoxin of Helicobacter pylori. Mol Microbiol 1996, 20:241-246.

9. Cover TL, Blaser MJ: Purification and characterization of the vacuolating toxin from Helicobacter pylori. J Biol Chem 1992, 267:10570-10575.

10. de Bernard M, Arico B, Panini E, Rizzuto R, Grandi G, Rappuoli R Montecucco C: Helicobacter pylori toxin VacA induces vacuole formation by acting in the cell cytosol. Mol Microbiol 1997, 26:665-674.

11. Leunk RD: Production of a cytotoxin by Helicobacter pylori. Rev Infect Dis 1991, 13(Suppl.8):S686-S689.

12. Atherton J, Cao P, Peek R, Tumurru M, Blaser M, Cover TL: Mosaicism in vacuolating cytotoxin alleles of Helicobacter pylori. Association of peptic vacA types with cytotoxin production and peptic ulceration. J Biol Chim 1995, 270:17771-17777.

13. Peek RM, Thompson SA, Atherton JC, Blaser MG, Miller GG: Expression of a novel ulcer-associated $H$. pylori gene, iceA, following adherence to gastric epithelial cells. Gastroenterology 1996, 110(Suppl):A225

14. Forsyth MH, Atherton JC, Blaser MJ, Cover TL: Heterogeneity in levels of vacuolating cytotoxin gene (vacA)transcriptionamong Helicobacter pylori strains. Infect Immun 1998, 66:3088-3094.

15. Fox JG, Dewhirst FE, Fraser GJ, Paster BJ, Shames B, Murphy JC: Intracellular Campylobacter-like organism from ferrets and hamsters with proliferative bowel disease is a Desulfovibrio sp. J Clin Microbiol 1994, 32:1229-1237.

16. Go MF, Cissell L, Graham DY: Failure to confirm association of vacA gene mosaicism with duodenal ulcer disease. Scand J Gastroenterol 1998, 33:132-136.

17. Gzyl A, Berg DE, Dzierzanowska D: Epidemiology of cagA/vacA genes in $H$. pylori isolated from children and adults in Poland. J Physiol Pharmacol 1997, 48:333-343.

18. Jorgensen M, Daskalopoulos G, Warburton V, Mitchell HM, Hazell SL: Multiple strain colonization and metronidazole resistance in Helicobacter pylori-infected patients: identification from sequential and multiple biopsy specimens. J Infect Dis 1996, 174:631-635.

19. van Doorn LJ, Figueiredo C, Sanna R: Clinical relevance of the cagA, vacA, and iceA status of Helicobacter pylori. Gastroenterology 1998, 115:58-66.
20. Yamaoka Y, Kwon DH, Graham DY: A M(r) 34,000 proinflammatory outer membrane protein (oipA) of Helicobacter pylori. Proc Natl Acad Sci USA 2000, 97:7533-7538.

21. Farhana K, Abid MH, Irshad A, Sriramula S, Manjulata DS, Ahmed AM, Rajender K, Aleem AK, Leonardo AS, Niyaz A: Comparative genomics of Helicobacter pylori isolates recovered from ulcer disease patients in England. BMC Microbiol 2005, 5:32-42.

22. van Doorn LJ, Figueiredo C, Mégraud F, Pena S, Midolo P, Queroz DM, Carnero F, Pegado MD, Sanna R: Geographic distribution of vacA allelic types of Helicobacter pylori. Gastroenterology 1999, 116:823-830.

23. Vildan C, Mustafa Y, Nadir Y, Sevil Z, Nedim K, Ilknur K, Huseyin B: H pylori iceA alleles are disease-specific virulence factors. World J Gastroenterol 2007, 13:2581-2585.

24. Yamaoka Y, Kodama T, Gutierrez O, Kim JG, Kashima K, Graham DY: Relationship between Helicobacter pylori iceA, cagA and vacA status and clinical outcome: studies in four different countries. J Clin Microbiol 1999, 37:2274-2279.

25. Al Oabandi A, Mustafa AS, Siddique I, Khajah AK, Madda JP: Distribution of vacA and cagA genotypes of Helicobacter pylori in Kuwait. Acta Trop 2005, 93:283-288.

26. Kidd M, Lastovica AJ, Atherton JC, Louw JA: Heterogeneity in the Helicobacter pylori vacA and cagA genes: association with gastroduodenal disease in South Africa? Gut 1999, 45:499-502.

27. Zheng PY, Hua J, Yeoh KG, Ho B: Association of peptic ulcer with increased expression of Lewis antigens but not cagA, iceA, and vacA in Helicobacter pylori isolates in an Asian population. Gut 2000, 47:18-22.

28. Salih BA, Abasiyanik MF, Ahmed N: A preliminary study on the genetic profile of cag pathogenicity-island and other virulent gene loci of Helicobacter pylori strains from Turkey. Infect Genet Evol 2007, 7:509-512.

29. Anderson H, Loivukene K, Sillakivi T, Maaroos HI, Ustav M, Peetsalu A, Mikelsaar M: Association of cagA and vacA genotypes of Helicobacter pylori with gastric diseases in Estonia. J Clin Microbiol 2002, 40:298-300.

30. Lyudmila B, Rumiana M, Daniel Y, Maya M, Katusha I, Stephan P, Galina G, Ivan M: High prevalence of virulent Helicobacter pylori strains is symptomatic Bulgarian patients. Diag Microbiol and Infect Dis 2009, 64:374-380.

31. Laila FN, Ismail M, Kamal BH, Marwa I: Helicobacter pylori genotypes identified in gastric biopsy specimens from Jordanian patients. BMC Gastroenterol 2006, 6:1-6.

32. van Doorn $L$, Figueiredo C, Rossau R, Jannes G, van Asbroek M, Sousa JC, Carneiro F, Quint WG: Typing of Helicobacter pylori vacA gene and detection of cagA gene by PCR and reverse hybridization. J Clin Microbiol 1998, 36:1271-1276.

33. Gonzalez-Valencia G, Atherton JC, Munoz O, Dehesa M, la Garza AM, Torres J: Helicobacter pylori vacA and cagA genotypes in Mexican adults and children. J Infect Dis 2000, 182:1450-1454.

34. Kersulyte D, Chalkauskas H, Berg DE: Emergence of recombinant strains of Helicobacter pylori during human infection. Mol Microbiol 1999, 31:31-43.

35. Dubois A, Berg DE, Incecik ET, Fiala N, Heman-Ackah LM, Del Valle J, Yang M, Wirth HP, Perez-Perez Gl, Blaser MJ: Host specificity of Helicobacter pylori strains and host responses in experimentally challenged nonhuman primates. Gastroenterology 1999, 116:90-96.

36. Tumurru MK, Cover TL, Blaser MJ: Cloning and expression of a highmolecular mass major antigen of Helicobacter pylori: evidence of linkage to cytotoxin production. Infect Immun 1993, 61:1799-1809.

37. Peek RM, Thompson SA, Donahue JP, Tham KT, Atherton JC, Blaser MJ, Miller GG: Adherence to gastric epithelial cells induces expression of a Helicobacter pylori gene, iceA, that is associated with clinical outcome. Proc Assoc Am Physicians 1998, 110:531-544.

38. Versalovic J, Koeuth T, Lupski JR: Distribution of repetitive DNA sequences in Eubacteria and application to fingerprinting of bacterial genomes. Nucleic Acids Res 1991, 19:6823-6831.

doi:10.1186/1476-0711-9-10

Cite this article as: Ben Mansour et al:: Prevalence of Helicobacter pylori vacA, cagA, iceA and oipA genotypes in Tunisian patients. Annals of Clinical Microbiology and Antimicrobials 2010 9:10. 